\title{
Taxonomic and faunistic notes on Hydrotaea unispinosa Stein, 1898 (Diptera: Muscidae)
}

\author{
Заметки по таксономии и фаунистике Hydrotaea unispinosa \\ Stein, 1898 (Diptera: Muscidae)
}

\author{
Nikita E. Vikhrev', Ilya A. Gomyranov ${ }^{2}$ \\ Н.Е. Вихрев, И.А. Гомыранов
}

\begin{abstract}
${ }^{1}$ Zoological Museum of Moscow University, Bolshaya Nikitskaya 6, Moscow 125009, Russia. E-mail: nikita6510@ya.ru Зоологический музей, МГУ им. М.В. Ломоносова, Большая Никитская ул., 6, Москва 125009, Россия.

${ }^{2}$ Department of Entomology, Lomonosov Moscow State University, Vorobiovy Gory 1-12, Biological Faculty, Moscow 119991, Russia. E-mail: gomyranov@yandex.ru

Кафедра энтомологии, Биологический факультет МГУ им. М.В. Ломоносова, Воробьевы Горы 1-12, Москва 119991, Россия.
\end{abstract}

KEY WORDS: Hydrotaea unispinosa, Hydrotaea silva, Hydrotaea gandakiana, Muscidae, Diptera, new synonymies

КЛЮЧЕВЫЕ СЛОВА: Hydrotaea unispinosa, Hydrotaea silva, Hydrotaea gandakiana, Muscidae, Diptera, новые синонимы

ABSTRACT. The situation with records of Nearctic Hydrotaea unispinosa Stein, 1898 from Asia is clarified. H. unispinosa is actually present in N Oriental and E Palaearctic regions. New synonymies are proposed: H. unispinosa $=$ Hydrotaea silva Hsue, 1976 syn.n. = Hydrotaea gandakiana Shinonaga, 1994, syn.n.

РЕЗЮМЕ. Прояснена ситуация с азиатскими находками неарктической Hydrotaea unispinosa Stein, 1898. Мы пришли к выводу, что H. unispinosa pacпространена в восточной Палеарктике и на севере Ориентального региона. Предложены новые синонимы: H. unispinosa = Hydrotaea silva Hsue, 1976, syn.n. = Hydrotaea gandakiana Shinonaga, 1994, syn.n.

\section{Introduction}

Treating Hydrotaea specimens collected in last years and preserved in Zoological Museum of Moscow University (ZMUM), we identified the series collected in the North part of the Oriental region as Hydrotaea gandakiana Shinonaga, 1994 described from Nepal, with several remarkable modifications of hind leg which make this species easily recognizable. Later on we used the key for Chinese Hydrotaea [Xue et al., 2007] and came to Hydrotaea unispinosa Stein, 1898, but this species was described from the Nearctic region [Stein, 1898]. In present paper we tried to clarify the situation.

\section{Material and methods}

The specimens listed are in the Zoological Museum of Moscow University (not indicated in text) or in the
Museum für Naturkunde, Humboldt-Universität zu Berlin, Germany (ZMHU).

Localities are given as follows: country, region, geographical coordinates in the Decimal Degrees format.

The following generally accepted abbreviations for morphological structures are used: $f 1, t 1, f 2, t 2, f 3, t 3=$ fore-, mid-, hind- femur or tibia respectively; $a c-$ acrostichal setae; $d c-$ dorsocentral setae; $a, p, d, v=$ anterior, posterior, dorsal, ventral seta(e).

Hydrotaea unispinosa Stein, 1898

Figs 1-6.

Hydrotaea unispinosa Stein, 1898: 165. Type locality: Canada, Ontario and USA, Colorado.

Hydrotaea silva Hsue, 1976: 109, syn.n. Type locality: China, Laoning prov., Yingbi-Shan $\left[40.7^{\circ} \mathrm{N} 123.1^{\circ} \mathrm{E}\right]$.

Hydrotaea gandakiana Shinonaga, 1994, syn.n. Type locality: Nepal, Gandaki prov., Kaski, Ghandruk, [28.38 $\left.{ }^{\circ} \mathrm{N} 83.81^{\circ} \mathrm{E}\right]$.

Hydrotaea calcarata Loew, 1858: Xue, Chao, 1998: 894 \&

Fig. 2063G, misidentification.

Hydrotaea silva Hsue, 1976 [1978 in author's text]: 109: Shinonaga, 2002.

Hydrotaea unispinosa Stein, 1898: Xue et al., 2007.

MATERIAL EXAMINED: India: Uttarakhand state: Surkanda Devi, $30.406^{\circ} \mathrm{N} 78.288^{\circ} \mathrm{E}, 2500 \mathrm{~m}$ asl., 9-10.IX.2011, N. Vikhrev, 1 ; ; Uttarkashi env., $30.745^{\circ} \mathrm{N} 78.455^{\circ} \mathrm{E}, 1200 \mathrm{~m}$ a.s.l.,

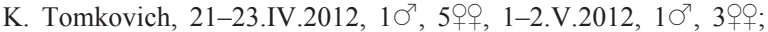
West Bengal state, Kalimpong, $27.06^{\circ} \mathrm{N} 88.43^{\circ} \mathrm{E}, 400 \mathrm{~m}$ a.s.1., $16-$ 30.XI.2013, K. Tomkovich, 19; Thailand, Chiang Mai prov., $19.28^{\circ} \mathrm{N} 98.61^{\circ} \mathrm{E}, 1350 \mathrm{~m}$ a.s.1., 15-18.XI.2010, N. Vikhrev, 1 \% Vietnam, Lai Chau prov., Sa Pa env.: $22.35^{\circ} \mathrm{N} 103.77^{\circ} \mathrm{E}, 1900 \mathrm{~m}$ asl, 5.IV.2011, $10^{7}$, A. Ozerov, $22.34^{\circ} \mathrm{N} 103.78^{\circ} \mathrm{E}, 2070 \mathrm{~m}$ a.s.l., 30.IV.2013, T. Galinskaya, $10^{7}, 22.35^{\circ} \mathrm{N} 103.77^{\circ} \mathrm{E}, 1900 \mathrm{~m}$ a.s.l., 22.V.2014, A. Ozerov, $10^{\prime}, 22.389^{\circ} \mathrm{N} 103.786^{\circ} \mathrm{E}, 1650 \mathrm{~m}, 23 . \mathrm{V}$. 2014, D. Gavryushin, 10'; USA, WA, Mt. Constitution. 17.V.10, Melander, $10^{\text {T }}$ (ZMHU), with Stein's identification label.

DESCRIPTIVE NOTES. Male: black species, body length $5 \mathrm{~mm}$ (Fig. 1). 

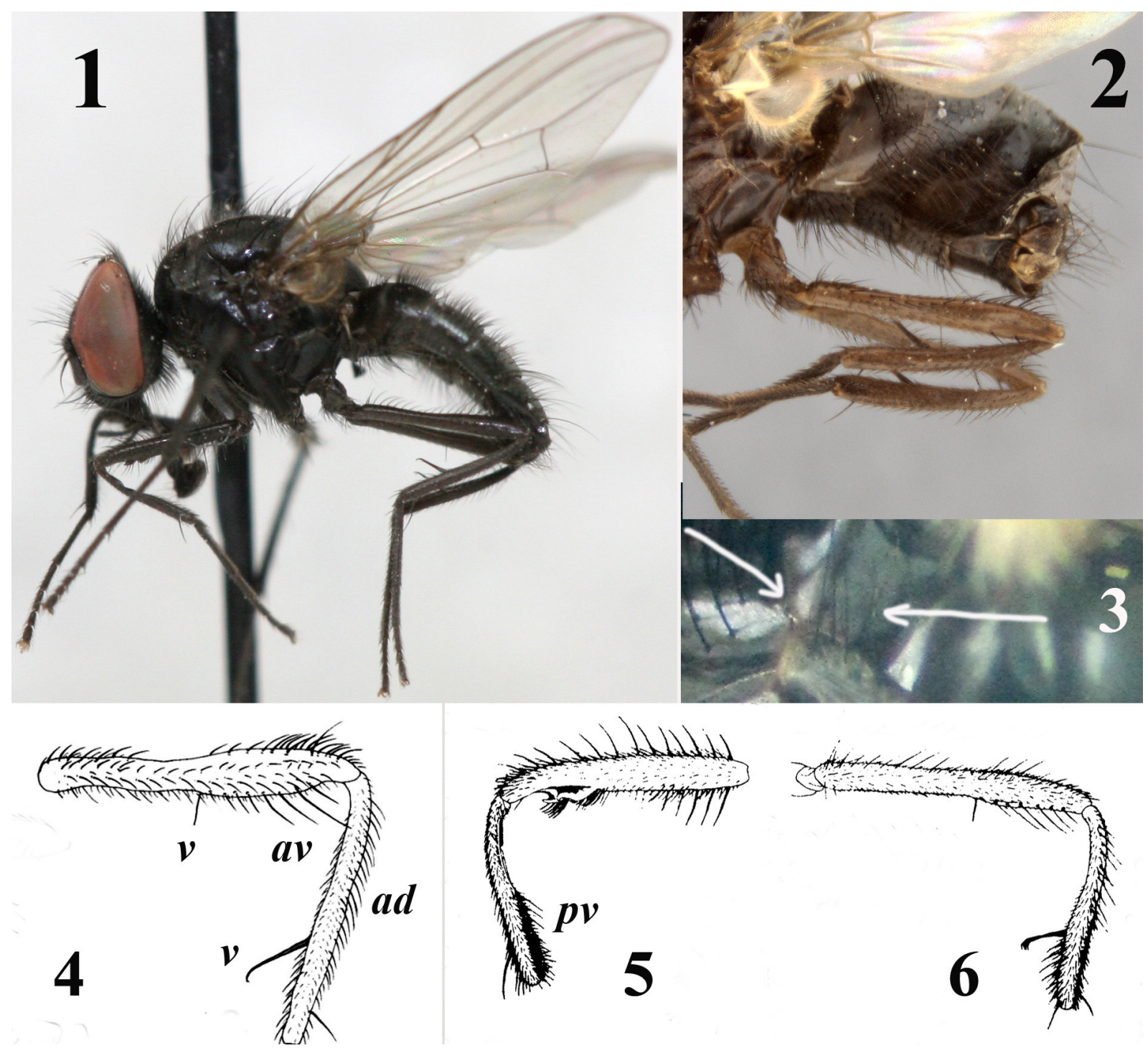

Figs 1-6. Hydrotaea unispinosa Stein, 1898: 1 - $0^{7}$ from India, Uttarakhand; 2 - $0^{7}$ from USA, WA (ZMHU); 3 - setulae on $0^{7}$ katepimeron; $4-\bigcirc^{7}$ hind leg (by Shinonaga \& Singh [1994] as H. gandakiana); 5 - $\sigma^{7}$ fore leg; 6 - $\sigma^{7}$ hind leg (by Hsue [1976] as $H$. silva).

Рис 1-6. Hydrotaea unispinosa Stein, 1898: $1-\sigma^{7}$ из India, Uttarakhand; 2 - $\sigma^{7}$ из USA, WA (ZMHU); 3 - щетинки на

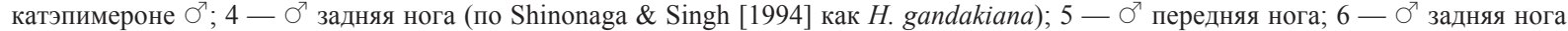
(по Hsue [1976] как H. silva).

Head. Eyes almost bare, with sparse and short hairs. Fronto-orbital plates touch in middle. Fronto-orbital plates, interfrontalia, parafacials, gena and occiput matt black. Fronto-orbital plates shining in lower third, with about 9 pairs of inclinate setae in lower half. Antenna black, arista with longest hairs 1.5x longer than basal diameter of arista. Palpi black.

Thorax entirely shining black, densely covered with long ground setulae. Chaetotaxy: $0+1 a c ; 2+4 d c$; katepisternal $1+1$, meron bare, katepimeron with 4-5 rather strong setulae (Fig. 3); notopleuron hairy. Wing clear, calypters yellow, haltere black.

Legs. $f 1$ with two typical ventral hooks at apex. $t 1$ emarginate on ventral surface in basal half; in apical half with a row of 2-4 fine $p v$ setae and several elon- gated hairs (Fig. 5). $f 2: p$ surface with a complete row of setulae; $a$ surface with a row of setulae in basal half and with 4-5 setulae at apex; $v$ surface with 4-5 spines in basal half, the penultimate spine the strongest; $p v$ surface in basal half with 4-5 weaker spines. $t 2$ with 2 strong $p$ setae and with a complete and dense row of elongated $a$ hairs (like that in Hydrotaea dentipes). $f 3$ with 3-4 av near apex and with thin and straight ventral spine slightly apicad middle. $t 3$ with apically curved ventral spur below middle consisting of 5-6 setulae; with 1-3 fine downcurved $a v$ setulae below spur; with a dense row of elongated ad setulae in basal 2/3 (Figs 1,4,6). Tarsi not modified.

Abdomen black, grey dusted with black median vitta on tergites 3-4. 
Female differs from male as follows. Frons wide, with interfrontal setae, a pair of proclinate and 2 pairs of reclinate orbital setae. Fronto-orbital plates and upper half of parafacials shining. Thoracic ground setulae shorter, prst ac in 5-6 irregular rows. Calypters white. Legs without modifications: $f 1$ without hooks at apex; $t 1$ without emargination and fine $p v$ near apex; $f 2$ without ventral spines and $p$ row of setulae, but $a$ setae in basal half and $1-2$ at apex are present; $t 2$ without dense $a$ hairs; $f 3$ without $v$ spine; $t 3$ without ventral spur, with $1 \mathrm{av}$ and $1 \mathrm{ad}$ below middle. Abdomen evenly subshining black.

Diagnosis of female. The identification of females of Hydrotaea is problematic except several cases. $H$. unispinosa is one of such lucky cases due to the presence of 2(1-4) rather strong and easily visible setulae on the katepimeron. Additional characters: the frontoorbital plates and upper half of parafacials glossy; $a c$ hairs in about 6 rows; arista pubescent.

\section{Discussion}

The modified hind leg (Figs 1, 4, 6) make identification of males of $H$. unispinosa rather easy except one difficulty. In the key for Chinese Hydrotaea [Xue et al., 2007] H. unispinosa is said to have the katepimeron hairy and all our specimens from India, Thailand and Vietnam also have the katepimeron with 2-5 distinct setulae. But the setulae on the katepimeron were not mentioned neither in Stein's [1898] description of $H$. unispinosa nor in Shinonaga's [Shinonaga, Singh, 1994] description of $H$. gandakiana. Besides records of the Nearctic $H$. unispinosa from the Oriental region also seemed doubtful. Fortunately, we had a possibility to examine in ZMHU an American specimen collected in USA, WA, Mt. Constitution and identified as H. unispinosa by Paul Stein himself (Fig. 2). This male was found similar to our ZMUM material in all characters including the setulae on katepimeron. Thus, the setulae on katepimeron were most probably just missed in Stein's and Shinonaga's descriptions and H. unispinosa Stein, 1898 = Hydrotaea gandakiana Shinonaga, 1994, syn.n. The taxon was described one more time as Hydrotaea silva Hsue, 1976, this time even the setulae on katepimeron were mentioned (as "baret hairy"). Later [Xue, Chao, 1998] listed H. silva as a synonym of $H$. calacarata Loew, 1858. Shinonaga [2002] listed H. silva for Indonesia (Bali, $1000 \mathrm{~m}$ asl) without any taxonomical comments. In [Xue et al.,
2007] H. unispinosa was for the first mentioned by Chinese authors as a species which differs from $H$. calcarata by presence of the ventral spine on $f 3$ and the setulae on katepimeron (here Hsue W.-C. and Xue W.Q. is the different Latin spellings of the same Chinese author name). In our opinion $H$. calcarata is a doubtful species with the type material lost. Anyway, according to the original description $H$. calcarata has densely hairy eyes, so $H$. silva is not its synonym, but $H$. unispinosa Stein, 1898 = Hydrotaea silva Hsue, 1976, syn.n. This synonymy is important for clarification of the geographical distribution of $H$. unispinosa because the type locality of $H$. silva is Laoning province of China which is certainly in the Palaearctic region. Thus, H. unispinosa is distributed in 3 ecozones:

- Nearctic: Canada and USA from East to West between $40^{\circ} \mathrm{N}$ and $50^{\circ} \mathrm{N}$;

- Oriental: foothills in the northern part of the ecozone: India: Uttarakhand and West Bengal; Nepal; Thailand, Chiang Mai; Vietnam, Lai Chau. Also probably Indonesia, Bali.

- E Palaearctic: China, Laoning.

Such a distribution is rather unusual but not unique, for example, Hydrotaea armipes Fallén, 1825 also has a Nearctic, Palaearctic and North Oriental distribution.

ACKNOWLEDGEMENTS. We thank Joachim Ziegler (Berlin) for the important material from ZMHU. We want to express our thanks to Oleg Kosterin (Novosibirsk) and Dmitry Gavryushin (Moscow) for help and corrections of the text. Work of I. Gomyranov was partially supported by RFBR, research project No.13-04-01638_a.

\section{References}

Hsue W.-C. 1976. One new species and three new records of the genus Hydrotaea from China (Diptera: Muscidae) // Acta Entomologica Sinica. Vol.19. No.1. P.109-111.

Stein P. 1898. Nordamerikanische Anthomyiden. Beitrag zur Dipterenfauna der Vereinigten Staaten // Berliner Entomologische Zeitschrift [1897]. Vol.42. P.161-288.

Shinonaga S. 2002. Record of the muscid flies collected in Indonesia (Diptera, Muscidae) // Medical Entomology and Zoology. Vol.53(Supplement 2). P.181-212.

Shinonaga S., Singh M.M. 1994. Muscidae of Nepal Diptera. I. Muscinae, Stomoxyinae and Phaoniinae. // Japanese Journal of Sanitary Zoology. Vol.45(Supplement). P.99-177.

Xue W.-Q., Chao C.-M. 1998. Flies of China, Vol.1. Shenyang: Liaoning Science and Technology Press. 1365 pp. [In Chinese]

Xue W.-Q., Wang M.-F., Wang D.-D. 2007. The genus Hydrotaea (Diptera: Muscidae) from China, with description of three new species // Oriental Insects. Vol.41. P.273-291. 